\title{
Aleksandr Bogdanov's Tektology: A Proletarian Science of Construction
}

\author{
SIMONA POUSTILNIK \\ independent scholar, London, UK; email: simonapoustilnik@gmail.com \\ Commentary by CARLO ROVELLI
}

Keywords: Organization, Russian Darwinism, tektological podbor, tektological socialism, cinematic assembly

Russian Darwinism developed without Malthus - without the struggle for existence. There is a remarkable link connecting the understanding of the Russian Darwinists of 'natural podbor' as 'fine-tuning' by nature and Aleksandr Bogdanov's concept of tektological 'podbor' ('assembling') as the universal mechanism of the construction of any organization. Bogdanov's conception of the universal phenomenon of 'organization' as an expedient combination of active elements and his attempt to construct a collective tektological 'personality-organization' possessed a conceptual creative power and influenced the work of the Soviet Constructivists. Conceptions of 'assembling'similar to those expressed in Tektology provided Constructivists with a scientific rationale, projects and terminology for their experiments in a new 'production art'. They constructed expedient and functional art objects from a tektological point of view - as organizational art objects. Tektological 'podbor' - 'assembling' as a universal mechanism for construction - provided the Constructivists with a real method for constructing an expedient art-object by way of a 'cinematic assembly' of the elements. 


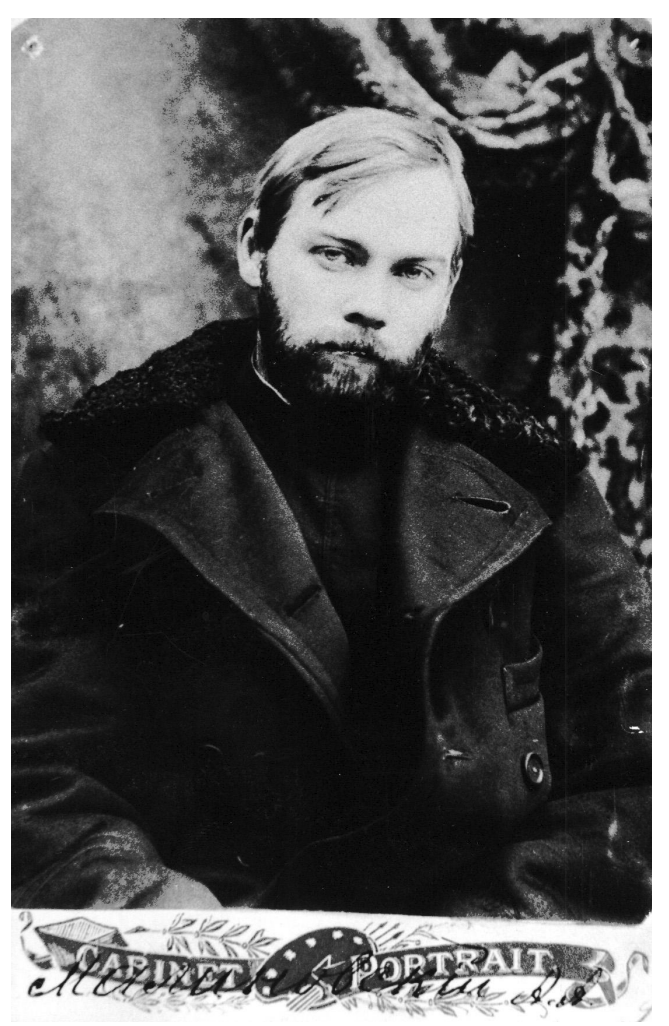

Image: A. A. Bogdanov in about 1904. Courtesy of Simona Poustilnik. Photograph discovered by Simona Poustilnik in the State Archive of the Russian Federation (GARF).

[T] he symbols and formulas of the Glass Bead Game[,] combined structurally, musically, and philosophically within the framework of a universal language, were nourished by all the sciences and arts, and strove in play to achieve perfection, pure being, the fullness of reality (Herman Hesse, The Glass Bead Game)

\section{'Furor tectologicus'}

Rephrasing René Descartes, Aleksandr Bogdanov once said of himself:'I am organized therefore I exist.' He viewed the phenomenon of 'organization'as a focal and creative point of the universe and Tektology as a universal science of organization of a better world and humankind. He admitted: 'I have some kind of disease - furor tectologicus - as soon as I see a task which is difficult to solve, or a combination I do not understand - so immediately appears the insurmountable aspiration if not to solve it, then to determine in principle its solution, and so for me nothing is sacrosanct' (Bogdanov 1913: 211-212).

Tektology: Universal Organizational Sciencel (1913-1922) signified the birth of a new science of organization (systems science in modern language) and a new cognitive model - a systems model. ${ }^{2}$ It would come fully into existence only several decades later, in the middle of the twentieth century, with the development of Ludwig von Bertalanffy's General Systems Theory (GST) and Norbert Wiener's cybernetics. ${ }^{3}$ But the true beginning of the systems paradigm was for a long time forgotten until

1 There is some disagreement regarding the date of publication of the first part of Tektology (1912 or 1913). The original was not dated beyond the foreword (December 1912) and Bogdanov himself occasionally referred to 1912. The definite date of publication (1913) is provided by the Knizhnaya letopis'in Rossiiskaya knizhnaya palata - year 1913, No. 32, page 4, entry number 19802.

2 The term 'cognitive model' was introduced by the Russian philosopher Alexander Ogurtsov in 1980 and developed by the Russian historian of science Yuriy Chaikovskiy. See Chaikovskiy 2008: 225-227.

3 Bertalanffy had arrived at his basic concept by the end of the 1930s, but published it only after the end of the war, having earlier believed that the scientific community was not ready to accept it. 
Bogdanov's Tektology was rediscovered. ${ }^{4}$ The starting point of Tektology was the universally applicable idea of 'organization' or 'complex' as an expedient unity, a combination of elements - 'activities-resistances' - and a universal set of organizational laws for all complexes of the world. As Bogdanov stated: 'My starting point ... consists in that structural relations can be generalized to the same degree of formal schematic clarity as the relations of quantities in mathematics and on such basis organizational tasks can be solved using methods analogous to the mathematical' (Bogdanov 1989: Book 2, 310).

This apparently purely scientific and innocent scientific doctrine gave rise to a great outburst of 'proletarian' debates and influenced the development, shaping and interpretation of proletarian ideology and culture in early Soviet Russia. This is not surprising since Tektology was designed as a monistic organizational proletarian science, and such a project was possible only in Russia and only at this time.

Bogdanov was deeply influenced by classical science and by the monistic tradition in philosophy. The idea of the unity of nature and of its simplicity was one of the first scientific and philosophical notions. It held that the diversity of nature was full of amazing and numerous analogies and repetitions - therefore, there should be simple and universal laws of nature to explain all phenomena. The epoch of classical science was an era of aspiration for the creation of 'global formulae' - universal and simple monistic models and concepts of the world. For pre-twentieth-century science, the unity of knowledge was equal to monism of knowledge - by ascending to more and more abstract levels of existence, it would be possible eventually to arrive at unified all-embracing laws of existence (as in the Mathesis universalis of Leibniz or the Divine Calculator of Laplace). ${ }^{5}$

This old monistic tradition was still very powerful during Bogdanov's lifetime. ${ }^{6}$ As the influential German biologist Ernest Haeckel ${ }^{7}$ put it, monism was an evident characteristic of the sciences and philosophical thought of the end of the nineteenth century. He believed that the approaching twentieth century would construct'a system of pure monism' and achieve the 'long-desired unity of world-conception' (Haeckel 1900: XV, 390).

Bogdanov designed his new science of organization in accordance with the monistic assumptions of his era - Tektology's subtitle; Universal Organizational Science, implies a monistic universal science. Tektology was to be a monistic science of world-organization, viewing and summing up the entire universe in terms of and through organization. ${ }^{8}$ Bogdanov's ingenious scientific discovery - 'everything is organization' - led him to the conclusion that everything was only organization - being a 'monist', he believed that he had created a new monistic organizational science. ${ }^{9}$

As a Marxist, Aleksandr Bogdanov was committed to the scientific reconstruction of society, which appeared to him to be the highest form of organization. Implementing Marxist-positivistic practical aspirations, tektology was to be not merely a monistic organizational science but a science of monistic

4 Tektology was a unique conception of the general science of organization which brought into focus the systems notions of all main macroparadigms which appeared at different stages in the development of the systems movement of the twentieth century. See Poustilnik 1998.

5 This idea was expressed in many ways in relation to both the simplicity of nature and the simplicity of its explanation (Ockham's Razor, Fermat's principle of the reflection and refraction of light, Maupertuis's general principle of least action, Goethe's protophenomena, etc.).

6 At this time, scientists were still preoccupied with analogies between the simple and the complex, and with the construction of numerous simple models of nature. For example, the analogy of the cell with the crystal was highly popular. See a Russian translation by Przhibram, G. 1913. 'Obzor mnenii avtorov o znachenii analogii mezdu kristallom i organizmom,' in What Is Life. New in Biology. St Petersburg: Collection 1, 19-47. We find this analogy in the first pages of Tektology. See Bogdanov 1989: Book 1, 72. For Bogdanov it was very important since it demonstrated the possibility of his general organizational approach.

7 Bogdanov took the term 'tektology' from Ernst Haeckel's 'Generalle Tektologie oder Allgemeine Structurlehre der Organismen' (1866), expanding that term. In Greek, 'tekton' means 'theory of construction' and, for Bogdanov, 'construction' was 'the most general and suitable synonym for the modern notion of organization'. See Bogdanov 1989: Book 1,112.

8 The German chemist Wilhelm Ostwald, Haeckel's most important successor as a monist, attempted to develop the concept of 'energetic monism', based on the universal principle of energy. This gave Bogdanov the idea of applying the notion of 'organization' in a similar way.

9 Bogdanov identified three types of monistic worldview in the history of society - religious, philosophical-abstract and scientific and considered tektology to be the ultimate 'scientific-monistic' worldview. 
organizational experience. Tektology was meant to be a practical science; its formulae - 'practical global formulae' - were intended for the 'practical mastery' of nature, and to be 'a powerful instrument of the real organization of humankind into a single collective' (Bogdanov 1989: Book 1, 110).

\section{Tektological 'podbor' - the Creative Power}

Russian Marxism had seen the Revolution and class struggle as the path towards achieving a new social order. Bogdanov had an opposite vision; the idea of struggle did not fit in with Bogdanov's organizational and harmonic vision of the world. Tektology was an 'all-human science' for the gathering together of man and the world, to produce a scientifically organized collective by stages of self-organization without class struggle. The collectivistic organizational logic of tektology was based on Bogdanov's biological worldview, fused with a Russian philosophical Weltanschauung, which had always been penetrated by ideas of the harmony of the world and did not accept the principle of struggle as the moving force of evolution.

Bogdanov introduced the term 'complex' as 'expedient unity' ('tselesoobrasnost') ${ }^{10}$ to denote a combination of elements or 'activities-resistances', and interpreted this in terms of the biological concept of constant interaction with the environment and adaptation to it (Bogdanov 1989: Book 1, 112-125).

Following Darwin, Bogdanov conceived of development as the adaptation of a complex to its environment. The universal regulating mechanism of tektological development and its adaptation was 'podbor'. Bogdanov believed his tektological podbor to be merely a logical extension of Darwin's principle of natural selection, discarding the epithet 'natural' (Bogdanov 1989: Book 1, 189-190). But he was mistaken in this.

How far did Bogdanov really follow Darwin? Was his conception of selection really an extension of Darwin's?

Darwin's theory of evolution 'by means of natural selection' was greatly influenced by the English economist Thomas Malthus and his theory of population growth exceeding resources. Malthus's metaphor of the 'struggle for existence' was the matrix for Darwin's theory of evolution based on competition. Darwin wrote: 'Nothing is easier than to admit in words the truth of the universal struggle for life' (Darwin 1902: 77).

Russian naturalists perceived nature very differently from Western naturalists, seeing in nature not over-population but under-population. Russian philosophy, with its humanistic and collectivistic tendencies, believed in the best sides of both human nature and society. The same attitude was applied to nature. As the Russian writer and publicist Aleksandr Herzen put it, everybody has to have a place at nature's feast.

For Russian intellectuals, the constructions of Malthus were offensive, even repugnant, and contrary to the Russian humanistic tradition, which believed in high human moral ideals and strove for the improvement of human society. ${ }^{11}$ These intellectuals transferred the same negative assessment to Darwin and Darwinism. Russian intellectuals perceived Darwin's theory as the concept of a ruling élite, for the benefit of the ruling élite. For example, the leading Russian biologist of that time, Nikolay Danilevskiy, described Darwinism as a 'purely English doctrine', in which was included not just the features of the English mind but all the features of the English spirit (Danilevskiy 1885: 178).

10 Bogdanov identified three types of complex - 'organized', 'disorganized' and 'neutral' - since an increase in the degree of organization ('organized' complex) was just one possible outcome of organizational processes; however, he was mostly interested in the 'organized' complex.

11 As Todes has noted, Malthus was seen in Russia as a 'hack writer' (Lev Tolstoi), whose doctrine was a 'morally repugnant' (Beketov) expression of the secret desires of the wealth-producing classes (Kropotkin). See Todes 1989: 169. 
In the first Russian translation of Darwin's Origin of Species (Rachinskiy 1864), Darwin's term 'natural selection' was translated as 'estestvenniy podbor' (remember that 'podbor' is 'assembling' in re-translation). This fundamentally changed the meaning of Darwin's concept of evolution and removed its emphasis on competition and struggle for existence. As a result, Russian Darwinism developed without Malthus - without the struggle for existence. Russian Darwinists and intellectuals discussed Darwin's theory of evolution in terms of 'assembling' or 'choice' - as nature's choice of individual traits with which to uphold its divine and marvellous order; adaptation represented a kind of reciprocal 'fine-tuning' or creative construction by nature (Chaikovskiy 1989: 121-141).

The correct translation of Darwin's term 'natural selection' - 'estestvenniy otbor'- appeared in Russia at the end of the nineteenth century, ${ }^{12}$ but the idea of competition as a moving force of evolution was not really adopted. Most Russian thinkers, philosophers and scientists of different backgrounds and political views of Bogdanov's generation believed that Darwin's concept of evolution reflected the negative influence of Malthus. In order to achieve 'genuine Darwinism', Russian thinkers tried to create different theories of mutual aid. In 1902 the famous Russian anarchist and biologist Prince Petr Kropotkin devised an alternative concept of evolution: Mutual Aid as a Factor of Evolution. ${ }^{13}$ In this work, Kropotkin wrote: 'I failed to find - although I was eagerly looking for it - that bitter struggle for the means of existence, among animals belonging to the same species, which was considered by most Darwinists... as the dominant characteristic of the struggle for life, and the main factor of evolution' (Kropotkin 1914: 7). Instead, he found 'a great deal of mutual aid where Darwin and Wallace see only struggle' (1914: 9).

Kropotkin did not deny the existence of competition within the same species or Darwin's concept of 'survival of the fittest'. But he believed that the 'fittest' are animals that co-operate with each other. Kropotkin viewed human morality as a product of the solidarity and self-sacrifice that originated from the co-operative instincts of the animal world. ${ }^{14}$

It was in conformity with this Russian anti-Malthusian assessment and tradition that Bogdanov wrote in Tektology that the principle of Darwin is a 'scientific truth' and that the views of Malthus should be disregarded 'as being fundamentally mistaken' (Bogdanov 1989: Book2, 190). He deliberately adopted the archaic, by that time, translation 'podbor'15 since, for him, it corresponded to genuine Darwinism. He believed that he was merely expanding the relevance of the term in Tektology, but, in fact, podbor ('assembling') as understood in Tektology is not an extension of Darwin's natural selection.

Darwin's evolution works only through heredity in the succession of generations. His natural selection meant selective biological reproduction; each generation continues its evolutionary direction by taking the next evolutionary step. In Bogdanov's tektological organizational scheme, the mechanism of 'podbor' was applied to the development of any kind of organization, regardless of biological heredity.

The most important difference, however, resides in the systems character of tektological 'podbor', which, in this respect, is the direct opposite of Darwin's 'natural selection'. Darwin's natural selection meant the selecting-survival of individuals through the adaptation of one particular feature or another in the course of the struggle for existence. Bogdanov's podbor meant the assembling-creation of the organization through the concordance of its parts and expediency (Bogdanov 1989: Book 1, 113) without reference to the idea of competition. Podbor in Tektology creates the mutual correspondence

12 In the translation of The Origin of Species by the famous Russian botanist Kliment Timiryazev (1896).

13 Petr Kropotkin 1914. Kropotkin wrote his book as a response to social Darwinism, particularly that of Thomas Henry Huxley (known as 'Darwin's Bulldog') and his book The Struggle for Existence in Human Society (1988).

14 Another great example of Russian collectivistic thinking is the Russian religious philosopher Nikolay Fyodorov, the father of Russian cosmism. In The Philosophy of the Common Task, he proposed bringing all people together in the global task of resurrection of all 'fathers' by the 'sons' through the application of science, in order to achieve immortality and the brotherhood of all generations in future cosmic humankind.

15 Bogdanov was familiar with the correct translation of Darwin's term 'natural selection' as 'otbor' since he was a student of Timiryazev and he applied the term 'otbor' in Tektology on several occasions. 
of all complexes as parts of a single world-organism - in line with the understanding of the Russian Darwinists of estestvenniy podbor as 'fine-tuning' in nature. ${ }^{16}$

Tektological podbor appears as the universal mechanism of the construction of any organization and its expediency. In 2008, Chaikovskiy, in his fundamental research on the theory of evolution, devoted a special chapter to 'Podbor' according to Bogdanov, where he discussed the importance of Bogdanov's podbor as the foundation of the idea of the universal phenomenon of self-organization in nature (Chaikovskiy 2008: 363-370). Tektological podbor as the universal organizing principle assembling the complex through the concordance of its parts was taken up later in the work of the Soviet Constructivists, as we shall see.

\section{'Tektological Socialism' According to Bogdanov}

It was not so much the functioning of organizations that interested Bogdanov as the principles by which an organization as 'expedient integrity' ('tselesoobrasnost') was constructed. Organization figures in Tektology more as a process than as a state - the new 'constructive' science was to be a science of the organizational laws that determine the construction of elements into an integral unity.

Bogdanov chose the category of 'organization' not by chance. The philosophical term 'organization' had acquired in Marxism a special meaning as 'social organization'. For Russian Marxists, the idea of the construction of a new rational social organization based on science was central - and science played a primary role in Bogdanov's conception of scientifically organized humankind. But he viewed the science of the old world as full of contradictions, too complicated and fragmented, and therefore not suitable for the purpose of managing the 'grandiose task ... the triple organization - of things, people and ideas' - the objective of which was to achieve a new social organization (Bogdanov 1989: Book 1, 106).

Bogdanov considered Marx to be the 'great forerunner of "organizational science"'. As White has put it, Bogdanov's concept of socialism as the 'gathering of man' was close to Karl Marx's original idea. Marx believed that socialism would create an integral human community which would end the fragmentation of the human psyche brought about by the division of labour and specialization. Bogdanov conceived of the future collective in a similar fashion - all of its members would be able to transfer from speciality to speciality. Science would be available to everyone and the human collective would be able to control it. But, for Marx, the future socialist society was to result from the inherent social nature of mankind, whereas for Bogdanov it would result from the active self-organization of society (White 1998: 37-38).

Bogdanov's answer was Tektology - the 'socialism of science'. In his early work The Gathering of Man (Sobiraniye cheloveka, 1904), Bogdanov formulated the task of changing 'fractured man' into 'integral man' when knowledge would be the property not of an élite but of all members of the collective. It was the hope of replacing the existing necessity of collective belief by the collective possession of knowledge that motivated Bogdanov in his path towards Tektology. ${ }^{17}$

The class struggle did not fit into Bogdanov's organizational vision of a harmonious world. As he explained in Problems of Socialism (Voprosy sotsializma, 1918), 'the class struggle ... ignores the

16 The modern understanding of 'selection' in the context of global evolutionism corresponds to Bogdanov's 'podbor'. See Poustilnik 2008: 134.

17 In Engineer Menni (1912), Bogdanov's second science fiction novel about 'tektological society' on the Red Planet, Mars, he gives expression to his innermost aspirations; one of the protagonists asks, 'What must we do so that we ourselves can know and see, and not just constantly believe?', adding that 'Modern science is just like the society that has created it: powerful, but splintered ... Because of this fragmentation the individual branches of science have developed separately and lost all vital connection with each other ... Each branch has its special language which is the privilege of the initiated and serves to exclude everyone else.'See Bogdanov 1984: 186-187. On Bogdanov novels, see Shushpanov 2009: 259-281. 
organization[al] stability of the social mechanism' (Bogdanov 1918: 42). He goes on: 'According to the old notions, socialism first conquers and then comes into being ... We see things differently socialistic development will be completed by a socialistic revolution' (1918: 101-102). The creative implementation of a socialist, class-based order will bring the proletariat to a victory that will transform that order into an all-human order ('obshchechelovecheskiy stroi').

Bogdanov completely discarded the notion of class struggle - now the construction of a new social organization could be achieved only through the long-term cultural self-organization of the proletariat. ${ }^{18}$ Bogdanov designed a programme for this transition - the Programme of Proletarian Culture (Proletkult). ${ }^{19}$ At the core of the project of the Proletkult there was tektology, the organizational proletarian science. To master culture meant to master tektology, which contained all the organizational experience and knowledge of humankind. For Bogdanov, tektology was the ultimate tool for the construction of new kinds of relationship among members of the social organization in the advance towards socialism. ${ }^{20}$

When Bogdanov says 'tektology', he means proletarian science, and vice versa. Tektology was a proletarian science that had simplified all sciences from an organizational point of view and so was available to every member of the collective, not just to the educated élite. This science of organization was a real instrument for achieving peaceful transition towards the unified human collective of the future. In Bogdanov's own words, tektology was an 'all-human science' - an instrument for the organization of humankind into a'single intelligent human organism ${ }^{21}$ - and the purpose of the Proletkult was to open the path towards socialism by serving as an enabling institution for cultural self-organization and the mastering of tektology.22

The Proletkult represented a fusion of Bogdanov's utopian aspirations - the scientific utopia of a universal monistic discipline that was capable of mastering any combination of elements and the social utopia of the construction of 'tektological socialism'.

\section{Project for Humanity and Project of Art}

How did Bogdanov's view of the world via the prism of organization influence Russian intellectuals in the first decades of the twentieth century? Vesa Oittinen, in his preface to Alexandr Bogdanov Revisited, has discussed the long history of Bogdanov's rivalry with Lenin and its powerful influence on the formation of Leninism and the early ideology, cultural politics and art of the Soviet state (Oittinen 2009: 7-20).

The post-revolutionary era in Russia witnessed the advent of a project to create a'new Soviet man'. This ideological construct was no longer an individual but a 'collective proletarian'. Many strands of this project were rooted in tektology, which during the early years of the Soviet regime was used by Russian Marxists as a creative intellectual tool. Political leaders and the 'proletarian'élite, both before the revolution and after, in their search for a new model human being and a new society, closely studied Red Star (Bogdanov 1908), Bogdanov's first science fiction novel about 'tektological communism' on Mars. During the first years after the Revolution, Bogdanov was very popular; tektology was a

18 This explains why he left active political life in 1911 and became Lenin's most serious intellectual antagonist and rival.

19 On the Proletkult, see Sochor 1988.

20 Bogdanov was obsessed with this idea. In 1918, at the First All-Russian Conference of the Proletkult, in his speech 'Science and the Proletariat' ('Nauka i proletariat'), Bogdanov spoke of the need to master tektology as a means towards socialism (the Proletkult catered not for everyone but primarily for the proletarian vanguard or proletarian élite).

21 Bogdanov tried to achieve 'physiological collectivism' in practice, through exchange of blood transfusions, seeing this as a way of eliminating the 'weak link' of each organism and, most interestingly, of achieving an 'outcome beyond the limits of individuality' (Bogdanov 1989: Book 2, 86). At that time, many scientists believed in heredity via blood. See Krementsov 2011.

22 In the 1920s, official Soviet Marxists distorted Bogdanov's notion of organizational proletarian science and used it to divide science into 'proletarian' and 'bourgeois'. 
mandatory subject of study in the courses of Narkompros (the People's Commissariat of Enlightenment). ${ }^{23}$ During the relative freedom of the 1920s, Bogdanov was still able to publish and express his views and ideas. ${ }^{24}$ The First All-Russian Initiative Conference on the Scientific Organization of Labour and Production (NOT), in 1921, opened with a presentation by Bogdanov - 'Organization Science and the Planning of the Economy' - in which he advocated the development of the Soviet economy according to tektological principles (the law of the least favourable conditions, the principle of equilibrium, etc.). ${ }^{25}$

In 1924, in the journal Under Banner of Marxism, it was noted that one of the journal's most immediate tasks was a close examination and criticism of Tektology from the standpoint of dialectical materialism (Veinstein 1924: 90) - indeed, critical reviews of Tektology appeared in this journal on a regular basis. ${ }^{26}$ In 1930, in the journal Revolution and Culture, it was emphasized once again that 'the influence of Bogdanov's doctrine ... necessitates its serious and deep criticism..27 In the same year, there appeared a critical review of the economist Bazarov, one of Bogdanov's followers in economics, in which it was sarcastically noted: 'What can we say about a naturalist who, on the grounds that a table has four "legs", like a cow, would declare that a table is the model of a cow?' (Sobol' 1930: 60).

Slava Gerovitch, in discussing the evolution of the Soviet notion of self, has pointed out: 'The "totalitarian model" of Soviet society traditionally considered "the cog in a wheel" as a central metaphor for the new Soviet type of human being. This metaphor embodied the notion of a passive individual subsumed under the collective ...' (Gerovitch 2007: 137).

Recently, however, scholars have begun to challenge the passive nature of the Soviet 'totalitarian self'. They argue that the 'new Soviet human being' was not just a passive recipient of official ideology; this new person, in aspiring after an alluring ideal, actively attempted to construct a new identity (Gerovitch 2007).

Proletarian collectivism was an essential feature of this identity and all aspects of a new'proletarian' life - and a necessary precondition of the construction of a new proletarian art. Bogdanov's slogan of 'organization' and organizational laws and his attempt to construct a collective integral personalityorganization possessed a creative conceptual power. As Susiluoto has pointed out, in Russia, systems thinking arose as a comprehensive challenge without proof, through philosophy and theoretical concepts, and possessed a 'utopian creative power to influence and change the entire world, now and at once' (Susiluoto 2009: 86).

Tektology as a science of the organization of rational combinations was a powerful and creative instrument, and its ideas were promoted and available to Soviet intellectuals, artists and the mass membership of the Proletkult. Many links were forged between groups of the Proletkult and the Constructivists after the founding of Constructivism in March 1921.28

The Art Deco style of the early twentieth century was a celebration of the rise of commerce and machine art: the human being was included in the universe of the machine and viewed as a technical system. During the early Soviet period, life was synonymous with art, and art became life. New

23 See Udal'tsov 1922: 82-83. The programme of the Proletkult abandoned traditional authoritarian teaching and relationships and encouraged students to work as a collective.

24 Particularly in the journals Gryadushchee (The Future) and Proletarskaya Kul'tura (Proletarian Culture). Bogdanov was the editor in chief of Proletarskaya Kul'tura.

25 It is interesting that Bogdanov introduced the term 'Soviet exhaustion' ('Sovetskaya iznoshennost'), which he considered to be a consequence of the 'enthusiasm of socialistic construction'. See Bogdanov 1928: 22.

26 For example, tektology was evaluated as reactionary concept because it 'interfered with the revolutionary tactics of the proletariat' (Veinstein ibid.); the tektological principle of the 'weak link' ('printsip slabogo zvena') provoked the 'Marxist' response that'our Party successfully leads the peasantry towards socialism, which is, "from Bogdanov's point of view[,] an impossible case" since for Bogdanov it is the "weak link" that determines development' (Karev 1926: 43); tektology 'results in almost mystical concepts because of the mechanical transfer of models from one area to another' (1926: 27).

27 'Ob itogach i novych zadachakh na filosofskom fronte' (1930: 109).

28 For example, Boris Arvatov taught at the Central Proletkult in Moscow. 
'proletarian' art and 'proletarian' art objects were to be imbued with the idea of a purpose that was understandable for the proletariat and clearly connected with everyday life and work experience. ${ }^{29}$

The Constructivists were dedicated to creating art objects that would organize the new Soviet man in a collective direction towards socialism. They were seeking to create the projects and objects of proletarian Constructivist art as a fusion of human being, technique, science and everyday life, based on the principle of concordance of the parts, forms and materials. ${ }^{30}$

Tektology provided Constructivists with a scientific rationale, and with terminology and models for their experiments in a new'production art'. Bogdanov viewed expediency as the universal principle of every form of organization, and considered that it derived from the inherent activity of all complexes: 'Any practical or theoretical task comes up against a tektological question: how to organize most expediently a collection of elements, whether real or ideal' (Bogdanov 1989: Book 1, 142).

For the Constructivists, the conception of 'organization' as an expedient combination of active elements was a powerful idea and stimulus. Tektological models demonstrated the practical ways for artists to construct an expedient complex of 'production art' in order to fulfil the political command which required proletarian artists to deliver practical and functional proletarian art objects.

In 1922, Aleksei Gan published the ground-breaking work Constructivism, in which he pronounced the slogan 'labour, technique and organization!';'expediency' was proclaimed a formal artistic dogma and goal. As Tikka has pointed out: 'In line with tectological thinking ... the constructivist theorist Alekseiy Gan ... elaborated his "Tectonics" on the idea of "fluidity" (tekuchest) as a formulation of the workers'"active social force"' (Tikka 2008: 222). ${ }^{31}$

Bogdanov spoke of the 'worker-organizer', the Constructivists of the 'artist-organizer'- both models implied collective work. Bogdanov conceived of tektology as the ultimate tool that would contribute to the attainment of socialism. The Constructivists saw collective artistic labour as a path towards socialism. Bogdanov did not make a distinction between creation and labour - and the Constructivists focused on practical objects inspired by labour, technique and everyday life.

The Constructivist artist was an 'artist-organizer', an 'artist-worker' - a member of the proletarian collective, organizing and creating an object of organized art in collective production. ${ }^{32}$ The product of constructivist work-art figured as an organized complex in Bogdanov's sense of the term created by the proletarian collective and representing the proletarian collective as 'worker-organizers'.

Tektological 'podbor' - 'assembling' - as a universal mechanism for construction provided the Constructivists with a real method for constructing an expedient art-object by way of a 'cinematic assembly' of the elements - in the manner of assembling by tektological 'podbor'.33 In 1922 the Constructivist Dziga Vertov proclaimed: 'Cinema is the art of the fictional motion of things in space that meet the requirements of science'; 'kinochestvo' is 'the art of organizing the necessary movements of things in space and time in a rhythmical artistic whole'.

In 1923, The Council of Three ('Sovet troich'), led by Vertov, proposed assembling 'visual events'into'a tectonic whole ... in a great craft of montage.' In this conception, the constructivist filmmaker would apply methods resembling tektological 'podbor' and tektological models as a means of creating organized film-construction. ${ }^{34}$ As regards tektological 'podbor' - assembling - Tikka has drawn attention

29 Aleksandr Rodchenko, in writing about the new essence of proletarian items of daily life, referred to 'the capitalistic world's "opium of things"'.

30 Alekseiy Gan designated the three principal elements of Constructivism as 'construction', 'faktura' and the 'tectonic'.

31 The term 'tectonic' ('tektonika') was also used by Constructivists Varvara Stepanova and Alexandr Rodchenko. Stepanova, in her 1921 lecture on Constructivism, discussed 'tectonic construction' and the role of the artist as an organizer.

32 For example, Rodchenko asked his students to create the objects which would organize the collective.

33 See Vertov, 1922. Variant Manifesta 'My': http://vertov.ru/Dziga_Vertov/

34 Dziga Vertov's Man with a Movie Camera (1929) is a great example of tektology-inspired Constructivist cinematic technique in which organized film is placed at the service of the organized collective. Vertov included in his films moments of editing of the film, making explicit the process of construction. 
to the ideas of Sergei Eisenstein on the cinematic 'assembly line' and to his 'notion of montage as a tectological method for organizing human experience' (Tikka 2009: 229).

\section{Conclusion}

I have argued that there is a remarkable link connecting the understanding of the Russian Darwinists of'natural podbor' as 'fine-tuning' by nature, Bogdanov's concept of tektological 'podbor' as a universal principle of 'assembling' in organization and, through what seems to have been the dissemination of his ideas, the concept of the 'cinematic assembly' of the Soviet Constructivists. In my view, this continuity can be attributed to the immanent collectivism of the Russian and Soviet Weltanschauung.

The conceptions of a new class of organizers of socialism as a'proletarian'collectivity - Bogdanov's tektology as organizer and Constructivist production art as organizer - were not acceptable to the Soviet political leadership since they did not integrate the leadership's conception of Marxism into their organizational constructions and models. The fraught relationship between these two great Utopian projects of the twentieth century has yet to be fully investigated.

\section{Commentary by Carlo Rovelli}

I met the ideas of Aleksandr Bogdanov only recently, while writing a book on foundational issues raised by modern science. Quantum physics challenges naive forms of reductionism and materialism, such as those defended by Lenin in Materialism and Empiriocriticisms. Bogdanov's criticism of Lenin's book recognizes and captures exactly the mistake which is still today at the root of the confusion about quantum theory: misunderstanding relationality for subjectivity, and viewing a naive materialism based on a scientifically outdated understanding of matter as the only alternative to idealism. This is why I inserted an extensive digression on the Lenin-Bogdanov debate into a book about modern physics.

Since this initial encounter, the ideas of Aleksandr Bogdanov have had a steadily increasing influence on my thinking and views. I find more and more that organization as a central notion for understanding natural processes, from atomic physics to chemistry, from biology to society, is a powerful intellectual tool that allows us to address open questions that range from ontology (I think that contemporary structural realism, fashionable in analytical philosophy, owes an unrecognized intellectual debt to Bogdanov's ideas, for instance) to concrete scientific questions.

Simona Poustilnik's text on the relations between Bogdanov's idea and Darwinism, on the one hand, and between it and the Constructivists, on the other, has added still further layers to my fascination with the extraordinarily rich legacy of Bogdanov's thought. In the context of evolution theory, in particular, the never-ending scientific debate on group selection and on the exact relation between competition and collaboration is still vital, and it seems to me that it would benefit from a re-reading of the ideas of the early twentieth century. As a scientist, I find Bogdanov's thinking deep and solid. As a human being, I find his political views subtly seductive. 


\section{References}

Bogdanov, A. 1908. Krasnaya zvezda (Roman-utopiya). Saint-Petersburg: Tovarishchestvo khudozhnikov pechati.

Bogdanov, A. 1913. Pis'mo V.V.Veresaevu", 3 November 1913. Trudy Komissii po nauchnomu naslediyu A.A.Bogdanova. Moscow: Institut Ekonomiki. 1992, 211-212.

Bogdanov, A.1918. Voprosy sotsialisma. Moscow: Knigoisdatel'stvo Pisatelei v Moskve.

Bogdanov, A. 1928. Perviy god raboty Instituta perelivaniya krovi. Na novom pole. Moscow: Gos. Nauchnij Institut perelivaniya krovi, 1, 1-45.

Bogdanov, A. 1984. Red Star. The First Bolshevik Utopia. Graham, Loren R and Stites, (Ed.), Bloomington: Indiana University Press.

Bogdanov, A. 1989. Tektologiya:Vseobshchaya organizatsionnaya nauka. Moscow: Economika, 1-2.

Chaikovskii, YV. 1989. Pervye shagi darvinisma v Rossii. Istoriko-biologicheskie issledovaniya, Moscow10: 121-141.

Chaikovskii, YV. 2008. Aktivnyy svyaznyy mir. Moscow: Tovarishchestvo nauchnuch izdanii KMK.

Danilevskii, NY. 1885. Darvinism. Kriticheskoe Issledovanie. SPb: Izdanie Merkuriya EleazarovichaKomarova, Vol.1, Part. 2.

Darwin, C. 1902. The Origin of Species by means of natural selection or The preservation of favoured races in the struggle for life. London: John Murray.

Gan, A. 1922. Konstruktivizm,Tver': Tverskoe izdatel'stvo.

Gerovitch, A. 2007. "New Soviet Man" Inside Machine: Human Engineering, Spacecraft Design, and the Construction of Communism." In Eghigian, Greg, Killen, Andreas and Leuenberger, Christine (Ed.), The Self as Project: Politics and the Human Sciences in the Twentieth Century, Osiris 22(1), University of Chicago Press, 135-157.

Haeckel, E. 1900. The Riddle of the Universe. London: Rationalist Press.

Karev, N. 1926. Tektologiya ili dialektika. Pod znamenem marskizma, Moscow, 4.

Krementsov, N. 2011. A Martian Stranded on Earth: Alexander Bogdanov, Blood Transfusions, and Proletarian Science. Chicago: University of Chicago Press.

Kropotkin, P. 1914. Mutual Aid: A Factor of Evolution. London: William Heinemann.

Kropotkin, P. 1930 Ob itogach i novych zadachakh na filosofskom fronte. Revolutsiya i kul'tura, Moscow, 1930, 9-10, 107-112.

Oittinen, V. 2009. Preface. Oittinen, Vesa (Ed.), Aleksandr Bogdanov Revisited. Helsinki: Aleksanteri Series, 1, 7-20.

Poustilnik, S. 1998. Biological Ideas in Tektology. Biggart, J., Dudley, P., King, F. (Ed.), Alexander Bogdanov and the Origins of Systems Thinking in Russia. England: Ashgate, 63-73.

Poustilnik, A. 2008. Bogdanov's Tektology and the Genesis of Systems Theory. Plaggenborg, Stefan und Soboleva, Maja (Ed.), Alexander Bogdanov. Theoretiker für das 20. Jahrhundert. Munchen: Sagner, 116-140.

Shushpanov, AN. 2009. Alternative Social Ideas in Russian Utopian Novels and Science Fiction at the Beginning of the 20th Century," in Oittinen, Vesa (Ed.), Aleksandr Bogdanov Revisited Helsinki: Aleksanteri Series, 1, 259-281.

Sobol, V. 1930. Teoriya planirovaniya vreditelya Bazarova, in Revolutsiya i kultura, Moscow, 21-22, 59-66.

Sochor, Z. 1988. Revolution and Culture. The Bogdanov-Lenin Controversy. Ithica and London: Cornell University Press.

Susiluoto, I. 2009. The Unfulfilled Promise: Tectology and "Socialist Cybernetics". Oittinen, Vesa (Ed.), Aleksandr Bogdanov Revisited. Helsinki: Aleksanteri Series, 1, 81-104.

Tikka, P. 2009. Tracing Tectology in Sergei Eisenstein's Holistic Thinking. Oittinen, Vesa (Ed.), 
Aleksandr Bogdanov Revisited. Helsinki: Aleksanteri Series, 1, 211-234.

Todes, D. 1989. Darwin Without Malthus: The Struggle for Existence in Russian Evolutionary Thought. Oxford: Oxford University Press.

Udal'tsov, A. 1922. K kritike teorii klassov u A.Bogdanova. Pod znamenem marksizma, Moscow, 7-8, 82-100.

Veinstein, I. 1924. Tektologiya i taktika. Pod znamenem marksizma, Moscow 1924, 6-7, 90-96.

Vertov, D. 2008. My. Variant Manifesta. Dziga Vertov. Iz naslediya. Moscow: Eisenstein-tsentr, 2.

White, James. 1998. Sources and precursors of Bogdanov's Tektology. Biggart, J., Dudley, P., King, F. (Ed.), Alexander Bogdanov and the Origins of Systems Thinking in Russia. England: Ashgate, 25-42.

\section{Authors information}

Simona Poustilnik, PhD studied History of Science at the Institute for the History of Science and Technology, Russian Academy of Sciences in Moscow. Her PhD thesis was titled 'Biological Ideas of A. A. Bogdanov's Tektology: The Genesis of General Systems Theory.' Her main research interests are in the history of twentieth-century Russian science, particularly systems theory, evolutionary theory and Bolshevistic science. Her special interest is Bogdanov's tektology, Russian Darwinism and development of proletarian science during the first post-revolutionary decades. She is a member of the British Society for the History of Science and the Authors and Publicists International Association (APIA).

Carlo Rovelli is a theoretical physicist known for his work in quantum gravity. He was born in Italy and has worked in the United States, France and Canada. Rovelli is a member of the Institute Universitaire de France, honorary professor of the Beijing Normal University, Honoris Causa Laureate of the Universidad de San Martin, Buenos Aires, member of the Académie Internationale de Philosophie des Sciences. In 1995, he was awarded the Xanthopoulos Award for'the best relativiste worldwide under forty'. He has written global bestsellers among which are Seven Brief Lessons on Physics, translated in more than fifty languages, The Order of Time and the recent Helgoland on quantum theory. He has been included by the Foreign Policy magazine in the list of the 100 most influential global thinkers.

\section{○ \\ OPEN ACCESS}

Copyright: @ 2021 The Author(s). This is an open-access article distributed under the terms of the CreativeCommons Attribution 4.0 International License (CC-BY 4.0), which permits unrestricted use, distribution, andreproduction in any medium, provided the original author and source are credited. See http://creativecommons.org/licenses/by/4.0/. 